Etnográfica

Revista do Centro em Rede de Investigação em

Antropologia

vol. 22 (1) | 2018

Vol. $22(1)$

\title{
Transnational studies twenty years later: a story of encounters and dis-encounters
}

os estudos transnacionais vinte anos depois: uma história de encontros e desencontros

\section{Federico Besserer}

\section{(2) OpenEdition}

Journals

Electronic version

URL: https://journals.openedition.org/etnografica/5172

DOI: 10.4000/etnografica.5172

ISSN: 2182-2891

\section{Publisher}

Centro em Rede de Investigação em Antropologia

\section{Printed version}

Date of publication: 1 February 2018

Number of pages: 109-130

ISSN: 0873-6561

\section{Electronic reference}

Federico Besserer, "Transnational studies twenty years later: a story of encounters and disencounters", Etnográfica [Online], vol. 22 (1) | 2018, Online since 17 May 2018, connection on 19 January 2022. URL: http://journals.openedition.org/etnografica/5172 ; DOI: https://doi.org/10.4000/ etnografica. 5172

\section{(c) (i) (2)}

Etnográfica is licensed under a Creative Commons Attribution-NonCommercial 4.0 International License. 


\section{Transnational studies twenty years later: a story of encounters and dis-encounters}

\section{Federico Besserer}

This article supports the argument that the researches on transnationalism and cultural studies had moments of confrontation and that, in these discussions, they influenced each other positively. I will try to expose this relationship from my own anthropological experience. The work concludes with a concern about the way in which the emergence of transnational actors is forming part of a new hegemonic formula for the functioning of political economy. Therefore, I will argue that the discussion in the researches on transnationalism and on the cultural studies should help to build a critical theory of the current moment, for which I propose five lines of work.

KEYWORDS: transnational studies, cultural studies, transnational theory of mediation, specular ethnography.

Os estudos transnacionais vinte anos depois: uma história de encontros e desencontros - Neste artigo se sustenta o argumento de que as pesquisas sobre o transnacionalismo e os estudos culturais tiveram momentos de confrontação e que, nestas discussões, se influenciaram mutuamente de maneira positiva. Tratarei de expor esta relação desde minha própria experiência vinculada à antropologia. O trabalho conclui com uma preocupação sobre a maneira como o surgimento de atores transnacionais está formando parte de uma nova fórmula hegemônica de funcionamento da economia e da política. Por isto, defenderei a importância de que a discussão nas pesquisas sobre o transnacionalismo e nos estudos culturais ajude na construção de uma teoria crítica do momento atual, para o qual proponho cinco linhas de trabalho.

PALAVRAS-CHAVE: estudos transnacionais, estudos culturais, teoria transnacional da mediação, etnografia especular.

BESSERER, Federico (feder@xanum.uam.mx) - Department of Anthropology, Universidad Autónoma Metropolitana - Unidad Iztapalapa, México. 


\section{INTRODUCTION}

It has been 20 years since I gave a presentation at the Colegio de Michoacán, in Mexico, where I tried to summarize the theoretical approaches to what in those years began to be called "transnationalism" (in order to differentiate it from its use in the field of economics to refer to the study of transnational companies). ${ }^{1}$ At the time, there was already scholarly reference to "transnational studies" that came to consolidate institutionally after "cultural studies," whose rise had begun 30 years before. By 1996 the journals Public Culture, which referred to the "Society for Transnational Studies," and Diaspora, which put itself forward as a "Journal of Transnational Studies," were already in existence.

My presentation reflecting on transnational processes was a little different from how the subject was discussed in the literature that was circulating at the time, which was fundamentally related to studies on migration. In that presentation, the meeting was small and with graduate students. It centered on the theoretical framework I had used for my doctoral dissertation, as well as some "postcards" (a genre I had learned from Nestor García Canclini to share fieldwork in process). A year later, I presented the written paper formally, at the Colegio de Michoacán's $19^{\text {th }}$ Colloquium of Anthropology and Regional History, in the city of Zamora.

That work had two characteristics that I would like to highlight. The first was that it did not only refer to migratory phenomena, that is, it did not center on what has been termed "migrant transnationalism." The paper focused on how the concept of "community" - or, to be more specific, "transnational community" - was approached by different currents of the literature on transnationalism. The argument was that this literature did not necessarily refer to processes of migration, but also postulated that there was a perspective that saw the "transnational condition" as a new historical moment in which the state and its relationship with the nation were redefined. For many, this was indeed a "transnational moment."

The second characteristic was that, drawing from the contributions of feminist epistemology, I proposed a "transnationalism of rupture" that involved the researcher and the migrant subjects themselves. In so doing, I discussed some approaches that broke with the "objectivism" of transnational studies as they were developing in anthropology and sociology in order to move toward theories that used the concept "transnational" in a way that resonated with conversations in the humanities, particularly postcolonial studies and cultural studies. The title of the original work shifted from "A journey through theoretical approaches on transnational communities and four postcards of the 
community of San Juan Mixtepec" and was eventually published as "Transnational studies and transnational citizenship" (Besserer 1999).

The work proposed integrating studies of "transnationalism," on the one hand, with "cultural studies" and "postcolonial studies," on the other, within the broad spectrum of what could be considered "transnational studies." Because I had studied for one master's degree developing a transnationalist focus within the framework of anthropology, and later received a master's degree in another department with a focus on cultural studies, the integration of these theoretical orientations made sense from the perspective of my own formative experiences. Yet my proposal became immersed in a larger dispute between the two approaches (what I call "objectivist" and "of rupture"), whose tensions were explicitly expressed in texts by authors relevant to transnationalism such as Aihwa Ong (1999) and Michael Kearney (2004). This tension has been addressed again in more recent works by Sanjeev Khagram and Peggy Levitt (2008), and Rainer Bauböck and Thomas Faist (2010), which provide an integrative effort through the same concept I chose in 1999 - that of "transnational studies."

In the following paragraphs I will try to support the argument that studies on transnationalism and cultural studies have had moments of confrontation, and through these debates have mutually influenced the other in a positive way. I seek to show this relationship through the perspective of my own experience within the context of anthropology. The paper concludes with a concern for the ways in which the emergence of transnational actors forms part of a new hegemonic formula for the functioning of economics and politics. Thus I argue for the importance of generating discussion in studies of transnationalism and in cultural studies that help build a critical theory for the current moment - a task for which I suggest five promising areas of work, including a transnational theory of mediation and a specular ethnography.

\section{THE DISCIPLINARY CRISIS OF ANTHROPOLOGY}

\section{AND THE EMERGENCE OF "TRANSNATIONAL STUDIES"}

The first uses of the concept "transnational" in the field of anthropology can be traced to the early decades of the $20^{\text {th }}$ century, when Edward Sapir used "transnational" to reflect on the economic and political processes that framed the cultural changes of his era. Sapir argued that it was not possible to think of a "generalized international culture," and national cultures also did not seem to have the potential to establish themselves without "cultural impoverishment." In the future, he thought, individuals would rather be linked to "a series of autonomous cultures," as "New York and Chicago and San Francisco will live each in its own cultural strength," framed in this transnational context (Sapir 1924: 428-429). 
In 1946, students at Columbia University in New York City, with a critical perspective in anthropology, formed the "Mundial Upheaval Society." Among the members of this group were Sidney Mintz and Eric Wolf (Hakken and Lessinger 1987: 6). These and other anthropologists (such as Ángel Palerm), associated with what in the postwar period was euphemistically called "political economy," engaged years later in the debate over world systems theory and, being critical of it, made alternate proposals to its Eurocentrism. Eric Wolf (1987 [1982]) worked on "people without history," Sidney Mintz (1996 [1985]) analyzed the role of the labor of Caribbean communities in the construction of capitalism on a world scale, and Ángel Palerm (2008a [1980]) proposed a model to understand the central role of the peasantry in shaping the first world system.

In the framework of this critical discussion on world-scale processes, prefaced by Eric Wolf, Ángel Palerm (2008b [1980]) argued that both Marxism and anthropology were in crisis, biased by the ideological veil associated with the figure of the nation-state. He explained that anthropology in England, France, and the United States had taken their own specific forms, which were linked to their role within colonialism. Concomitantly, he said, Marxism was trapped within the ideologies of countries in which socialism was dominated by a new class associated with the political and techno-administrative apparatus of the state.

Palerm proposed that Marxism needed anthropology to understand and escape from nationalism, but anthropology needed Marxism to build a conceptual framework that could distance itself from colonialism. From my point of view, Palerm describes in 1980 a process that was already taking place at that moment: the construction of "transnational" studies both at the level of research and at the level of the transformation of the discipline itself.

In anthropology, "disciplinary nationalism" was entrenched at different levels. The first of them was related to the very structure of the discipline as it was organized in each country. For example, British social anthropology consisted of three subdisciplines: economic anthropology, political anthropology, and symbolic anthropology. Here, anthropology was aligned with other disciplines such as economics, political science and sociology, but its focus of study was "other societies." In contrast, the North American school was organized by the "four-fields approach" which included archaeology, physical anthropology, linguistic anthropology, and the study of culture. French ethnology also did not share these disciplinary structures.

The changes in the discipline announced by Palerm were already in operation at several levels. In the case of British anthropology, the return of the gaze towards the metropolis as a field of cultural study - driven partly by Marxist historians and partly by colonial subjects' scrutiny of British society - called into question the "I-Other" distinction that not only organized fields of study, 
but sustained the tacit division between the knowing subject and the societies to be known. This tension critiqued the disciplinary boundaries that divided the field of knowledge between the metropolis and its colonies; transformed the hierarchy of the "knowing" epistemic group with respect to the societies "to be known"; and changed the "object" of disciplinary study, resulting in the emergence of "cultural studies" as a critical, confrontational and trans-disciplinary project in that country.

In the case of Unites State's anthropology, the assumption that one could think of cultures as if they were contained within a territory (such as nations within a national territory) was challenged, to demonstrate that cultures extended beyond borders and that, therefore, we should understand "territories" as "border areas" of social convergence and juxtaposition of cultures under unequal conditions of power. The study of "border areas" and cross-cultural relationships broke with what years later Andreas Wimmer and Nina Glick Schiller (2002) would call "methodological nationalism." This was the working space of subjects who self-identified with complex identities, such as Chicano/a anthropologists, who brought the tools of literary criticism to the study of culture, reconfiguring the subdisciplinary alliance and introducing literature as a field that crossed through all subdisciplines. This "anthropology with literature" was one of the changes that led to the formation of "American cultural studies."

This move away from what we can call "methodological territorialism" in anthropology (the assumption that field research should begin by defining first the territory where the peoples we study would be contained) had many critical ramifications. For example, it broke with the further assumption that peoples in different territories lived in different stages of development or moments in human chronology - an error Johannes Fabian (1983) has called "allochrony."

Thus, the rupture of disciplinary nationalism in anthropology occurred on at least three levels: subdisciplinary reorganization and the questioning of the boundaries between disciplines; the emergence of a new knowing subject; and the recognition of power differentials and the political character of culture.

\section{CONFLICTS AND INTERPELLATIONS: TRANSNATIONALISM: INTER-DISCIPLINARY PARALLELS}

The effort to break with nation-centrism was not a process unique to anthropology, but rather took place in different disciplines, and for this reason, the process initiated an inter-disciplinary conversation where the concept "transnational" took on different connotations according to the academic context from which it originated.

Nye and Keohane (1971), for example, wrote about the problem of "state-centrism" in political science, which took states as actors in international relations. These scholars used the concept of "transnational" in order 
to invite the study of inter-domestic relations, the study of civil organization networks that transcended national borders, and the study of geographies such as international waters and outer space. With this concept, research was then expanded to supranational and subnational levels.

In the discipline of history, the concept of "transnational" has been used as a category that accounts for changes in the relationship between state and nation (Tyrrell 2001). Thus "transnational" is utilized in reference to pre-national times as well as the contemporary era, during which states are increasingly recognizing their diasporas, therefore changing the relationship between state and nation as we once knew it and moving toward a process that some have called post-national (Feldman-Bianco 2015).

In anthropology, criticism of "methodological nationalism" (Wimmer and Glick Schiller 2002) and the proposal of the concept of "transmigrant" (Glick Schiller, Basch and Blanc-Szanton 1992) have emphasized the continuation of the links constructed and maintained by subjects over time, leading to ethnographies about transnational communities (Kearney and Nagengast 1989; Besserer and Kearney 2006) and transnational migrant circuits (Rouse 1989), among other topics. This anthropological perspective can also be found in other social sciences scholarship, such as Laura Velasco's work on identity and leadership (Velasco Ortiz 2002, 2015). One strand of this research that centered on migration was developed as "migrant transnationalism" (Vertovec 2006).

"Transnational" therefore became a polysemic concept that could mean (to mention only some uses) "non-state," "cross-border" or "beyond the historical moment of the nation-state as we know it." This was the beginning of a process of parallel disciplinary tendencies that led to a current of thought that some have called "transnationalism" (Glick Schiller, Basch and Blanc-Szanton 1992).

\section{Cultural studies: trans-disciplinary juxtapositions}

If transnationalism was a process describing change that originated within the discipline, other challenges came from the disciplinary margins. This was the case for British cultural studies that, according to Stuart Hall (1990), arose from several situations at the margins of the disciplines. The first of these was that the promoters were "extramural professors" active in the labor movement of the time who had relocated from political practice to the academy. The second was that some of these academics did not originate from the centers of British power, but from rural life (such as Raymond Williams) or ex-colonies (such as Stuart Hall himself). Finally, they did not enter disciplinary structures, but came to a center formed by Richard Hoggart in Birmingham, where one of the central themes was to understand how mass culture was transforming what E. P. Thompson (1978) called the "class culture" of the workers.

The center was a place of convergence for two types of disciplinary crises. On the one hand, there was the crisis of the humanities in a "post-imperial" 
country that had to rethink the way in which it had constructed itself. This reconceptualization occurred primarily through and within the disciplinary structures of the humanities at universities such as Cambridge, which had been entrusted as gatekeepers of the "English language." On the other hand, the social sciences disciplines such as sociology did not grasp the key role played by cultural change in the political and economic transformation of English society at the time. This was why "culture" appeared as the preponderant topic at the center of two disciplinary crises, as the study of culture became incorporated in disciplines such as history and British anthropology (creating a confrontation with the division of labor that maintained that only anthropology was for the study of "others") drawing from Marxist authors such as Gramsci and those at the Frankfurt school. There was a theory to build, and Hall tells us that this project was not carried out in the lofty office of the academy, but in another "margin" of the disciplinary apparatus that is the classroom, with those students who were newcomers to university training. The case of Birmingham illustrates the convergence and juxtaposition of two disciplinary crises (that of the social sciences and that of the humanities) that explains why cultural studies was not merely an inter-disciplinary project but a trans-disciplinary one. Here I take the idea of "trans" as in transculturality, in the sense of two processes that inform each other and become a framework of hierarchical inequalities.

\section{The epistemic rupture}

A debate initiated by Nina Glick Schiller and George Fouron (1990) around the concept of "diaspora" can usefully illustrate the "epistemic break" (to borrow the concept from feminist epistemology) that was initiated in the 1990s between the disciplines that tended to rely on the concept of "transnationalism" and the transdisciplinary perspectives that we have called "transnational studies."

In this context, three transdisciplinary positions were to emerge onto the scene of the debate about transnational processes; these positions were associated with scholars who I describe as writing from their own de-centered conditions. On the one hand, there was cultural studies, which centered on the concepts of "diaspora" and the "diasporic intellectual." These positions attempted to break with "national" studies and use new geographical references or "transnational formations" such as the Black Atlantic (Gilroy 1993). It is a perspective that supports the possibility of building knowledge through "diasporic experience" (Morley and Chen 1996). On the other hand, postcolonial studies questioned the categories we use to understand reality - as it comes from experience or from academic abstraction -, proposing instead that we had to start with a critique of representation, as did Saïd in his work on "Orientalism" (Saïd 1990 [1978]). This shift allowed postcolonial studies to criticize the figure of "nativism" as a construction of post-colonial intellectuals, who 
represent themselves and their country by using the images that empires construct about their colony (Spivak 1989). As for feminism, it seems to me that its contribution was to the construction of an epistemology of transnationalism, which facilitated the in-depth study of nationalisms and their role in the construction of scientific categories - including the analysis of anthropological texts as part of the critical equation (Grewal and Kaplan 1994; Brah 1996).

\section{The distancing between transnationalism and transdisciplinary studies}

The debate between transnationalism and what we have called "trans-disciplinary positions" had moments of productive dialogue. An example of this can be found in a meeting entitled "Transnationalism, Nation-State Building, and Culture," which took place in Spain in 1994 under the auspices of the Wenner Gren Foundation. Bringing together scholars such as Bela Feldman-Bianco, Partha Chatterjee, Nina Glick Schiller, Stuart Hall, Michael Kearney, and Aihwa Ong, among others, the conference marked a moment in which it was possible to build an approach that might produce a multifaceted perspective through transnational studies.

However, at least within anthropology, this process took place in a period of crisis that has been called an "experimental moment of anthropology" (Marcus and Fischer 1986), during which, according to Marcus (1995), "methodological anxieties" grew. The disciplinary changes that had been provoked pushed anthropology to the point of rupture in some cases. At least, this was the case in the department where I studied, out of which formed two departments of anthropology - one as "anthropological science" and the other with a perspective critical of the "objectivist" position of the discipline (a situation that lasted for ten years). This tension within anthropology, which was expressed in disciplinary transnationalism's stance against transdisciplinary scholarship - in particular that of cultural studies - can be found in the arguments of two authors of great relevance to transnational thought: Michael Kearney and Aihwa Ong.

The concerns of Michael Kearney (2003 [1991]) had to do with the contribution of the anthropological discipline to the understanding of the human in a "robust" way. He worked in the Department of Anthropology at the University of California at Riverside, which was organized into four fields: archaeology, physical anthropology, linguistic anthropology, and cultural anthropology. He was preoccupied by what he identified as centrifugal forces within anthropology that tended to separate it by subdiscipline. The advent of "cultural studies" added an additional tension between humanistic and scientific anthropology. This tendency to separate, he thought, was probably one of anthropology's most significant challenges. It was the reason why he adopted an opinion critical of "cultural studies," which he perceived as a position that underestimated the importance of humans' biological substrate and of the ecological environment, though this problem has been an important topic of discussion in, for 
example, American literature (Segal and Yanagisako 2005). Kearney advocated the four-field approach in anthropology, but at the same time, he thought it necessary to keep within the same body of thought those studies on the material basis of existence with the humanistic approaches that interpret it. These two axes of integration were the premise for an integral theory that would allow a holistic analysis of the human. This, according to him, was a theoretical problem as well as a problem of the sociology of science, since the discipline requires epistemic groups of researchers who interact in order to think in harmony.

Aihwa Ong, the other prominent anthropologist of transnationality, also forcefully critiqued "cultural studies," which she saw as moving away from the "grand narratives," and with it the capacity to study the material aspects of the transnational condition. Her argument was that anthropologists' approach to the humanities after the Cold War ceded terrain to perspectives that took the study of culture as text, generating a "postcolonial, elite-driven discourse that ignores the structures of power in identity making and social change" (Ong 1999: 241). The risk, Ong maintained, was that the result of this interdisciplinary dialogue might be a "lite" anthropology unable to "capture the interplay between culture and the material forms of social life" (Ong 1999: 242). Since the beginning of her career, Ong's work has been characterized by an interest in the role of culture to understand the dynamics between subordination and resistance in the context of labor. Relying on Foucault (1988) to study the relationship between culture and capitalism, her work has highlighted the role of the "micro-technologies of power" through which subjects of capitalism regulate themselves. Because Foucault did not directly analyze the relationship between discursive practices and the systemic reproduction of capitalism, she has also drawn on the work of Frederic Jameson (1991: 291) to explain that cultural production has a basis in the symbolic reproduction of capitalism.

\section{Interpellations from cultural studies}

It is interesting to observe that from her first works, Ong shares with scholars of the field ironically named "American cultural studies" an interest in the theory of Foucault (see Rosaldo 1994) and the work of Frederic Jameson, whose systematic critique of the "cultural logic of capitalism" has been associated with cultural studies. In practice, it appears to me that cultural studies scholars, like Ong, have similarly called for the study of "material conditions," and others have pointed out the importance of not leaving out the interaction between subjects and "structure." To illustrate, I will briefly present two positions, that of Paul Gilroy and that of the so-called "Latin American cultural studies."

There has been reiterated use of the "transnational" concept within cultural studies. For example, Paul Gilroy proposed that the Black Atlantic is a "transnational and intercultural formation" (Gilroy 1993: ix). The concept "transnational" has been used in opposition to both "nationalist" movements that 
claim to be a nation, and "ethnicists" who propose to be an "ethnicity." For this reason, the Black Atlantic is a methodological proposition that is explicitly trans-national and inter-cultural in order to break with "nationalism" as both ideology and analytical method and with "ethnicism" for its essentialist perspective. The transnationalism of the population that was constructed as "black," argues Gilroy, was ironically facilitated by the transnational character of the slave trade. Slaves came from many different countries and religions, which led to fragmentary positions. For this reason, Gilroy proposes that it is better to consider the possibility of an "intercultural and transnational" unity, which is to say that recognition should not be based on a place of origin, or because some are more "ethnic" than others. Hence the Black Atlantic is a concept that breaks with the nation and with ethnic absolutism in order to constitute itself as intercultural and transnational.

The "transnational structures" that created the "black world" have now been replaced, Gilroy argues, by a transnational network of communication systems. "Diaspora" is therefore a central concept to the project - a theoretical tool that allows "counterpoints" (a concept previously used by the Caribbean thinker Fernando Ortiz) between particular specificities and a common sensibility derived from the experience of racialized slavery in the New World.

Thus Gilroy calls for the study of transnational processes on two levels: as a dynamic that occurs within an intercultural counterpoint that characterizes diaspora and that explains "double consciousness"; and as a way to characterize material conditions (such as slavery and the culture industry) that form the structural context in which these cultural dynamics are produced. Paul Gilroy's study focuses on the "transnational intellectual," whose transnational experiences are at the bases of theoretical innovations of transnationalism. Among these diasporic intellectuals are those who in the past experienced a world of slavery, and those who in the present produce in the communication and culture industries.

From his position within cultural studies, Gilroy emphasizes the importance of the material context that contributed to the construction of the transnational condition, but he does not delve too deeply here, as this is a task that transnationalist analysis has developed. In contrast, Gilroy prioritizes how lived experience within the transnational condition has raised certain contributions from "the margins" to academic thought, resulting in confrontations with the disciplinary apparatus.

In this essay, I cannot expand on the career of Renato Rosaldo, but I would like to incorporate his contribution to the debate in order to explain that a better grasp of what Raymond Williams (1977) called "mediation" is required to understand the dynamic between material and cultural processes. It seems to me that through the contributions of Ong and Gilroy, we can think about the importance of building a theory of mediation within contemporary capitalism 
in which disciplinary and transdisciplinary contributions converge. We will deal with this a bit later.

\section{The discomforts of Latin American cultural studies}

The way in which cultural studies are often referred to as "British" or "American" forces us to reflect on the problem of the "nationalities" of cultural studies. These "labels" play an ambiguous role. They emerge as echoes of theoretical nationalism, but simultaneously are intimately linked with the process of its transnational critique. For this reason, it seems to me that these are names that operate as "ellipses," and that concepts such as "the American School" would probably have to be read in the mode of Derridean deconstructionism with the first word crossed out. Thus "cultural studies" arose while critiquing the way in which "English literature" had been conceptualized or how "social history" did not include African descendants, their experiences, and their way of speaking English. In the same way, "American cultural studies" emerged by calling for a cultural reformulation of citizenship in that country, which has been based on an exclusionary form of nationalism.

It seems to me that the same process occurred for "Latin American cultural studies" (Szurmuk and Irwin 2009).

In the first place, this was because non-Latin American cultural studies were nourished partly by thinkers whose sociocultural context was that of Latin America and the Caribbean. In particular, we can think of Franz Fanon and Stuart Hall, whose life histories - including their departure from the Caribbean - would generate a transnational process that integrated Caribbean reality with European thought. This is true for other fields that have influenced the development of cultural studies, such as dependency theory and its influence on Wallerstein's thinking and, of course, the important work of Caribbean scholar Fernando Ortiz (1983 [1963]).

The same can be said for the case of Renato Rosaldo, whose "habitus" he shares with those of Mexican and Latin American origin in the United States - not only in everyday life, but in the discussion about its condition in the US academy. The struggle to identify a "Chicano literature" opens these transforming spaces of cultural studies that emerge as "transnational." It is not only an automatic influence of material conditions on thought. It is an effort to construct the conditions in which belonging might also allow for difference.

Second, the critical tradition also drew from the writings of non-Latin American studies in the construction of its theoretical framework under a diverse variety of situations. In particular, Thompson (1978) and Williams (1977) have been useful since the 1970s. We could also add the cases of scholars who studied, or are studying, in the departments in which these theoretical frameworks were developed. So the construction of subsequent studies projects cannot be distanced from non-Latin American studies for a variety 
of reasons, one of which is that scholarly networks that build and maintain bridges between the academies operate on many levels by mutually informing one another.

Third - and this to me seems of particular relevance -, Latin American and non-Latin American cultural studies work with subjects that are Latin American, but in many different places. This parallels the way in which scholars might put reality into analytical categories, but the subjects with whom we work coordinate between our realities and force us to put our analytical frameworks in dialogue. For example, Gilroy's work on the emergence of knowledge that he articulates around the concept of diaspora in the Black Atlantic context shows that the "black presence" of the late 1940s and onwards is an example of a theory of culture based on a transoceanic reality that escapes continental and sub-continental geographic divisions.

Some cultural studies groups from Latin America have criticized the approach emanating from the US academy, preferring instead the contributions of the Birmingham School precisely because of its political character and its commitment to the recognition of the economic context of culture. The argument I make here is that the proximity of Latin American cultural studies to the Birmingham School is due to the mutual recognition of the political and conflictive nature of culture, as well as the culturally constituted nature of politics and economics. Both are positioned within a project inspired by Marxist and neo-Marxist theories that include Stuart Hall and Raymond Williams as well as Antonio Gramsci, Ernesto Laclau, Chantal Mouffe - in addition to recognizing the importance of Fernando Ortiz, Carlos Mariátegui and Frantz Fanon, among others (Richard 2010).

It therefore seems clear that cultural studies share with the Center for Cultural Studies in Birmingham an emphasis on the mediation of Marxist thought and the study of culture in the context of power - that is, between the symbolic and the material world of capitalism. One example of this kind of work is the most recent book compiled by José Manuel Valenzuela Arce (2015) about youth cultures in contemporary capitalism.

It is true, as Rosana Reguillo (2003) says, that cultural studies scholars in Latin America have had skirmishes with the disciplinary structures that operate as technologies of power, because funding, cultural policies, and the process of specialization that bounds disciplinary objects of study have been resistant to the disruptive role of cultural studies. However, it is also true that there has been an institutionalization of cultural studies programs in Latin America and the Caribbean, which from my point of view must be understood, drawing from Gramsci, as strategies in a "war of positions" from which cultural studies can be identified as instances of critique.

It seems to me, then, that faced with the critical stance of disciplinary transnationalism, which demands as indispensable the study of the material 
conditions of the production of culture, cultural studies have recognized and apprehended this need from their own transdisciplinary positions and by using their own analytical tools.

\section{PROJECTS OF CONVERGENCE}

In recent years, there have been some efforts to construct bridges between the disciplinary studies of transnationality and transnational studies "of rupture." In the following section, I review two texts that use the concept "transnational studies" to link the different directions that studies on transnationality and transnationalism have taken.

The first text is written by Sanjeev Khagram and Peggy Levitt (2008). Khagram and Levitt argue that there are at different "intellectual foundations" within a new paradigm that one could refer to as "transnational studies."

First, there is an empirical transnationalism that has described transnational phenomena and dynamics; importantly, this provides information that allows us to know and categorize these realities. Second, the volume refers to methodological transnationalism that undergirds the possibility of constructing a new paradigm. It attempts to overcome the "methodological nationalism" that characterizes most instruments of data collection such as censuses and ethnographies that are based on political territories and subjects designated by the governing apparatuses of nation-states. Saskia Sassen's "global city" (1991) or Paul Gilroy's "Black Atlantic" (1993) would fall into the category of contributions that allow research at various levels of analysis. This category would also include methods of historical analysis that can account for processes that precede the configuration of nation-states and compare them with those we find in our contemporary moment.

The third type of contribution is categorized as theoretical transnationalism. This pillar includes reflections that have been made from disciplinary platforms, some of which propose that supra-national systems are emerging, transforming the importance of the nation-state system as we have known it. The fourth foundation suggested by the authors is philosophical transnationalism, which questions the stability of the very categories with which we think. That is, this philosophical plane questions the categories used by conventional theories in order to think of the categories as "results of social processes" and not as analytical starting points. The categories themselves must therefore be the object of meta-theoretical scrutiny. A new ontology and a new epistemology would be part of this philosophical enterprise to think about the nature of social worlds, and how new worlds can be analyzed and explained. Finally, public transnationalism treats transnational studies as a paradigm to explore how one might imagine other worlds where the construction of citizenship, security and governance can be thought without resorting to the model of nationalism. 
The Khagram and Levitt model is a good starting point for thinking about how to integrate a field of knowledge such as "transnational studies." Though this model is concerned with epistemological and ontological questions and incorporates authors of cultural studies and disciplinary transnationalism through the proposed "intellectual foundations," the very problem of these contradictions is not addressed. Therefore, it seems to me that there is room for this model to reflect explicitly on this predicament.

We have left until the end the book by Reiner Bauböck and Thomas Faist (2010), which makes an exercise of approaching the two projects commonly associated with the concept of "transnational community" and "diaspora," respectively. The work starts from categories used by different analytical frameworks to move forward in a categorical, methodological and theoretical approach that searches for convergence between various models in a tone similar to the work of Khagram and Levitt, also under the encompassing concept of "transnational studies."

\section{A SHADOW OVER TRANSNATIONAL STUDIES:}

\section{THE IMPORTANCE OF A CRITICAL THEORY}

I find it important to mention the work of Bauböck and Faist because it proposes that, beyond academic discussion (where concepts are presented as if they appear in tension), in everyday use, said concepts overlap. In fact - and this is what I find relevant - in recent years, as migration appears as a numerically growing phenomenon, the concept of "diaspora" has been used by states to recognize as nationals those people who can be found outside its national borders. Furthermore, the concept of "transnational community" has been increasingly used in language related to development and often in the context of the role played by migrant remittances as a "tool for the development" of domestic economies.

Bauböck and Faist clearly illustrate the emergence of a paradox, and this is that the strengthening of transnational communities and the capacity and agency of the transmigrant subjects is also the context in which new forms of subjection and dispossession appear in the transnational realm. Diasporas and transnational communities are collectivities that absorb the costs of economic and political crises; they are enterprising subjects that with a kind of docile agency (to use the Foucauldian concept) take care of themselves, in a transnationalized world that frequently keeps them in situations of multiple exclusion, or transnational exclusion. The state no longer interpellates them as subjects of welfare, but as agents of development (Besserer 2014).

We are thus in a moment in which the situation for transnational communities and diasporas has changed, and the dominant discourse has started to incorporate "the transnational" within its rhetoric. 
So at this moment it seems especially important to work on the construction of a critical analytical framework in transnational studies, because a productive dialogue between transnationalism (as the set of disciplinary proposals) and transdisciplinary approaches is essential to construct an apparatus capable of understanding the complexity of the current moment and build the conceptual instruments and academic practices that might contribute to the transformation of society.

\section{NEW INTERSECTIONS IN TRANSNATIONAL STUDIES}

In this paradoxical moment of transnational studies, I believe that it is important to encourage those agendas that might help us deepen its critical potential.

In this respect, I am personally interested in following five lines of work.

The first line of inquiry is of a general nature and consists of building a transnational theory of mediation. I am convinced that at the center of the construction of contemporary capitalism and its concomitant forms of governmentality is the emergence of a new cultural logic (as mentioned by Jameson 1991). The study of the material basis of this process, as well as its cultural dimension, requires understanding the dynamics of mediation (to use Williams' concept) that occurs between the two (Williams 1977). That is to say, it seems to me that it is important to construct a transnational theory that will necessarily require, as I have tried to demonstrate above, the concurrence of "objectivist" transnationalism with a perspective "of rupture," such as that found in cultural studies.

To conceive such a theory, I use the concept of mediation in two forms. First, following Raymond Williams, I understand social processes as a unity that is concurrently a material situation and its representation. We cannot separate "base" (often a realm of interest of transnationalism) from "superstructure" (often perceived as the area of research of cultural studies) because social processes are both material and the product of representation themselves. Therefore, a theory of mediation should study how representation and material life are articulated and mutually constituted. In second place, I use the concept of "mediation" to state that in our efforts to acquire knowledge about reality, this does not stand "transparent" in front of our eyes. Knowledge of social reality is always mediated by culture, by a particular social network, and by specific practices. Our representation is not a "second nature" but a cultural mediated perception of what we call "reality." I'm not referring only to "everyday knowledges," we should include in this cultural mediated construction of our subject of knowledge the representations produced by scientific activity and thought. Everyday knowledges and scientific knowledges often share elements of hegemonic cultural logic of a specific historic moment operating as a doxa, underlying orthodox and heterodox perceptions of reality. 
Some approaches from the cultural studies perspective support the idea that knowledge based on experience, that is, "practical knowledge," when strategically situated might generate a critical perspective over hegemonic cultural representations. Such is the case of the diasporic intellectuals who might have a bifocal view and a double consciousness derived from their subaltern point of view in society. Such "point of view theory" has been criticized by its lack of "objectivity" and scientific depth.

A theory of mediation should start by introducing a principle of symmetry (Hess 2001). In order to surpass "methodological nationalism," the transnationalist perspective aimed to correct what they found to be limitations of the scientific method in social sciences. Although there is a recognition that errors derive from the fact that disciplines grew from the "habitus" of the nation, corrections were made in terms of the rules of the own scientific method. Recognition of people's mobility and connectivity, the identification of transnational social spaces and the identification of supranational and subnational units of analyses, render empirically verifiable and replicable results. Following the contributions from feminist philosophy of science, this transnationalism could be identified as "strong transnational empiricism," where results can be verified in terms of the tools of the own scientific method. Transnationalism, as we have described in former sections of this paper, has criticized the "point of view" approach we find in cultural studies as it might introduce cultural biases when resourcing for their analyses to concepts such as "diaspora" used by transmigrants, which might carry and express religious underpinnings.

In this tension between transnationalism ("strong empiricism") and cultural studies ("point of view theory"), the principle of symmetry would require both sides from the transnational studies equation to be treated evenly. That is, if transnationalist approaches consider cultural studies to be less empirically anchored as desirable, and too culturally grounded; transnationalism should be reviewed not only in terms of its scientific capacity, but also in terms of the cultural assumptions it might reproduce. In this context, cultural studies of science have the theoretical and methodological instruments to undertake such an endeavor. Symmetry would demand therefore not only both extremes from transnational studies to pass the scientific exam, but also to understand to what degree both approaches are subject to the influence of culture, and in particular to the hegemonic cultural logic of dominant politics and economics.

Thus, transnational mediation theory should endorse a symmetric perspective where cultural studies help to see the elements of the dominant cultural logic imbricated in transnationalism, while transnationalism would be the means to support the analytical tools we find in cultural studies and other critical theories. A transnational mediation theory would be, as we can infer from the abovementioned ideas, an example of double reflexivity, as it requires objectivist and non-objectivist accounts to incorporate a self-referred 
and critical stand. A further characteristic of a transnational mediation theory should be that it would work as a connecting vessel among the topics of study developed by transnationalism and cultural studies. This leads us to two research topics developed by cultural studies that in my mind represent central topics for the development of transnational studies. These are the study of science as a subject of analyses, and the development of a political economy of affects. Both of this topics I will develop in the next paragraphs as I find them crucial for the understanding of current capitalism.

Thus, the second line of research is a critical theory of the sciences, an area of inquiry that has established new ways of understanding the construction of the social subject. Indeed, one of the spaces where this cultural struggle is waged is within scientific practice. We can find one example in the growing number of deaths in Mexico, which has led to changes in the dominant notions of the individual body and the social body. The disappearances of migrants have put at the center of the debate the notion of the body as a symbolic map. The textualization of the body is transformed into databases that forms part of the new "social body." On the one hand, the security of the population depends, to a great extent, on the management of these databases. On the other hand, practices such as forensic anthropology have demonstrated the role of the sciences in state policies that cover up the widespread violence that has occurred in the migratory corridors between Central America and the United States. In this moment, theory derived from the feminist anthropology of the sciences allows us to better understand the construction of a new discourse that is no longer based on "the social," but rather on a complex ensemble of signs and technologies that are in contention with the practices of civil society and the national and international apparatuses that control and manage information (Besserer 2016).

Third, it seems important to develop studies about power that have incorporated the concept of "transnational governmentality" to explore how power has been constructed in a moment in which the state has apparently "withdrawn" (Gupta and Ferguson 2002). A good example of this is the scholarship on deportations that have shown us that, in addition to the act of deportation, the self-construction of those subjects as "deportable" has had, in recent years, an important consequence on the demographic shifts between countries that were once categorized as "receiving" and those that traditionally have been "sending" workers on the international level (De Genova and Peutz 2010). This line of work about "power" permits us to refocus the discussion on the subject rather than a single-minded focus on the state, as do transnational studies of "politics" (Besserer and Nieto 2015).

Political economy of affect. In relation to the work on power, I am interested in contributing to the development of a political economy of affect that explains the subjective mode of transnational life in a moment in which we 
should better understand the markets and politics of nostalgia (Hirai 2009), such as those that can be found within the regimes of terror and the geographies of fear in, for example, the so-called "gray zone" of international migration (Guillot 2012). This approach permits us to think about transmigrants as subjects with agency, and reveals the tension between a docile agency, as Saba Mahmood (2008) illustrates, and the counterhegemonic practices that can be found in everyday life, such as (in)appropriate feelings (Besserer 2014).

Specular ethnography. In congruence with the above-explained transnational theory of mediation, I am interested in developing transnational ethnographic work that has the capacity to operate on both the level of empirical fieldwork, while simultaneously being informed by a critical theory such as cultural studies. Raymond Williams has demonstrated that art, culture and ideology are not a "reflex" of "reality," or of the material basis of society. For this reason, he substituted a theory of "reflex" for a theory of mediation in his project. However, I find useful the metaphor of the mirror and the reflex, to explain a possible ethnographic approach for transnational studies. There are two possible ways of describing specular ethnography.

The first approach is a rather empirical and straightforward definition, where "specular ethnography" is the recognition that the reality we see when we use the methodological lenses of nationalism, is partial. Specular ethnography would have the task of exploring the movements and connections of peoples beyond the borders of local fields of research (Besserer and Oliver 2014). However, specular ethnography goes beyond multi-sited ethnography, because it explores the fact that this reality is not an extension of social life as we find it at the local level. We are rather exposed to the fact that the expanded field of social life has been "filtered," "reclassified" or "inverted" by a dispositive of power as in the case of an international border. A Mexican campesino who crosses the border is re-classified, and becomes a "day-laborer," a mistranslation explained by Michael Kearney in - what I consider - his specular analyses of the triad "borders-orders-identities" (Kearney 2006). Specular ethnography may include the study of the "dispositive" itself, which might be an international border, or a radio station (Robles 2015).

A second definition of "specular ethnography" would focus on the cultural logic of current economy and politics, exposing the culturally-mediated construction of material life and society, exploring, for example, how new forms of global production transform fundamental notions of what nature is, and how a person is constituted (Besserer 2001).

Yet a third way of thinking "specular ethnography" relates with the ontological discussion of the knowing subject in transnational studies. Following Kearney, we may state that transnational studies have identified the reduction of the critical distance between the "anthropological self" and the "ethnographic Other." This implies a growing recognition of the fact that everyday 
people (self and Other) engage in ethnographic activities, live in resistance and contestation, and intervene at some point in the construction of critical narratives and theoretical analyses. This ethnography grows from the margins of the discipline, often becomes more than a form of collaboration in the field and rather a modality of "auto-ethnography," and a form of "auto-theory." Students in ethnographic training at departments of anthropology are an example of these incredible talented ethnographers who are at some point still at the margins of the discipline, speaking from their own diasporic "point of view," creating their own theoretical constructions, and putting anthropology into practice (Cinco 2017).

Thus, the aspect of the field entails more than a multi-sited approach: it requires, on the one hand, the recognition that the boundaries that fragment a reality under investigation frequently produce complementary and inverse realities at each end of said boundaries; and on the other hand, that the basic categories that inform a methodology are constructed. This specular ethnography should study the processes of cultural production in order to understand the circular relationship between cultural production and the culturally constituted character of material reality. Finally, a characteristic of this specular ethnography is that it begins from the "margins" of the discipline, incorporating the subjects with which we work as well as the students that start the research; both participate as knowing subjects in a process of collective reflection (Besserer 2016).

\section{REFERENCES}

BAUBÖCK, Reiner, and Thomas FAIST (eds.), 2010, Diaspora and Transnationalism: Concepts, Theories and Methods. Amsterdam, Amsterdam University Press.

BESSERER, Federico, 1999, "Estudios transnacionales y ciudadanía transnacional", in Gail Mummert (ed.), Fronteras Fragmentadas. Zamora, Colegio de Michoacán and CIDEM, 215-238.

BESSERER, Federico, 2001, "Luchas culturales en la agricultura del capitalismo tardío", Alteridades, 11 (22): 15-28.

BESSERER, Federico, 2014, "Comentarios críticos y cinco propuestas para pensar la migración en el momento actual”, Desacatos, 46: 88-105.

BESSERER, Federico, 2016, "Identidade nacional, identificação e corpo", in Brasilio Sallum Jr. et al. (eds.), Identidades. São Paulo, Editora da USP, 101-124.

BESSERER, Federico, and Michael KEARNEY (eds.), 2006, San Juan Mixtepec: Una Comunidad Transnacional Ante el Poder Clasificador y Filtrador de las Fronteras. México, DF, Universidad Autónoma Metropolitana and Casa Juan Pablos. 
BESSERER, Federico, and Daniela OLIVER (eds.), 2014, Ensamblando la Ciudad Transnacional: Etnografía Especular de los Espacios Transnacionales Urbanos. México, DF, Universidad Autónoma Metropolitana and Juan Pablos Editor.

BESSERER, Federico, and Raúl NIETO (eds.), 2015, La Ciudad Transnacional Comparada: Modos de Vida, Gubernamentalidad y Desposesión. México, DF, Universidad Autónoma Metropolitana and Juan Pablos Editor.

BRAH, Avtar, 1996, Cartographies of Diaspora: Contesting Identities. New York, Routledge.

CINCO, Mónica, 2017, “A Mi No Me Pueden Volver a Sacar”: Etnografía Práctica desde las Márgenes de la Diáspora Chino-Mexicana. México, DF, Universidad Autónoma Metropolitana, doctoral dissertation.

DE GENOVA, Nicholas, and Nathalie PEUTZ (eds.), 2010, The Deportation Regime: Sovereignity, Space, and the Freedom of Movement. Durham, NC, Duke University Press.

FABIAN, Johannes, 1983, Time and the Other: How Anthropology Makes Its Object. New York, Columbia University Press.

FELDMAN-BIANCO, Bela, 2015, "Desarrollos de la perspectiva transnacional: migración, ciudad y economía política”, Alteridades, 25 (50): 13-26.

FOUCAULT, Michel, 1988, “El sujeto y el poder”, Revista Mexicana de Sociología, 50 (3): 3-20. GILroy, Paul, 1993, The Black Atlantic: Modernity and Double Consciousness. New York, Verso. GLICK SCHILLER, Nina, and George FOURON, 1990, “"Everywhere we go, we are in danger': Ti Manno and the emergence of a Haitian transnational identity", American Ethnologist, 17 (2): 329-347.

GLICK SCHILLER, Nina, Linda BASCH, and Cristina BLANC-SZANTON (eds.), 1992, Towards a Transnational Perspective on Migration: Race, Class, Ethnicity, and Nationalism Reconsidered. New York, New York Academy of Sciences.

GREWAL, Inderpal, and Caren KAPLAN, 1994, Scattered Hegemonies: Postmodernity and Transnational Feminist Practices. Minneapolis, MN, University of Minnesota Press.

GUILlOT, Sandra, 2012, Poder y Violencia en la "Zona Gris": Un Análisis de la Situación de los Niños Salvadoreños Migrantes en los Espacios Transnaiconales desde la Antropología de las Emociones. México, Universidad Autónoma Metropolitana, Unidad Iztapalapa, B.A. thesis.

GUPTA, Akhil, and James FERGUSON, 2002, "Spatializing states: toward an ethnography of neoliberal governmentality”, American Ethnologist, 29 (4): 981-1002.

HAKKEN, D., and H. LESSINGER, 1987, Perspectives in U.S. Marxist Anthropology. Boulder, CO, Westview Press.

HALL, Stuart, 1990, "The emergence of cultural studies and the crisis of the humanities", The Humanities as Social Technology, 53: 11-23.

HESS, David J., 2001, "Ethnography and the development of science and technology studies", in Paul Atkinson et al. (eds.), The Sage Handbook of Ethnography. Thousand Oaks, CA, Sage Publications, 234-245.

HIRAI, Shinji, 2009, Economía Política de la Nostalgia: Un Estudio sobre la Transformación del Paisaje Urbano en la Migración Transnacional entre México y Estados Unidos. México, DF, Universidad Autónoma Metropolitana and Juan Pablos Editor.

JAMESON, Frederic, 1991, El Posmodernismo o la Lógica Cultural del Capitalismo Avanzado. Barcelona, Paidós Ibérica.

KEARNEY, Michael, 2003 [1991], “Fronteras y límites del yo al final del imperio”, Alteridades, 13 (25): 47-62. 
KEARNEY, Michael, 2004, Changing Fields of Anthropology: From Local to Global. Lanham, MD, Rowman and Littlefield Publishers.

KEARNEY, Michael, 2006, "El poder filtrador y clasificador de las fronteras", in Federico Besserer and Michael Kearney (eds.), San Juan Mixtepec: Una Comunidad Transnacional Ante el Poder Clasificador y Filtrador de las Fronteras. México, DF, Universidad Autónoma Metropolitana and Casa Juan Pablos, 31-72.

KEARNEY, Michael, and Carole NAGENGAST, 1989, Anthropological Perspectives on Transnational Communities in Rural California. Davis, CA, California Institute for Rural Studies (Working Group on Farm Labor and Rural Poverty, Working Paper No. 3).

KHAGRAM, Sanjeev, and Peggy LEVITT, 2008, The Transnational Studies Reader: Intersections and Innovations. New York and London, Routledge.

MAHMOOD, Saba, 2008, “Teoría feminista y el agente dócil: algunas reflexiones sobre el renacimiento islámico en Egipto”, in Liliana Suárez Navaz y Rosalva Aída Hernández Castillo (eds.), Descolonizando el Feminismo: Teorías y Prácticas desde los Márgenes. Madrid, Editorial Cátedra, 165-222.

MARCUS, George E., 1995, "Ethnography in/of the World System: the emergence of multisited ethnography", Annual Review of Anthropology, 24: 95-177.

MARCUS, George E., and Michael M.J. FISCHER (eds.), 1986, Anthropology as Cultural Critique: An Experimental Moment in the Human Sciences. Chicago and London, The University of Chicago Press.

MINTZ, Sidney, 1996 [1985], Dulzura y Poder: El Lugar del Azúcar en la Historia Moderna. México, DF, Siglo XXI.

MORley, D., and K. CHEN (eds.), 1996, Stuart Hall: Critical Dialogues in Cultural Studies. London, Routledge.

NYE, Joseph, and Robert KEOHANE, 1971, "Transnational relations and world politics: an introduction”, International Organization, 25 (3): 329-249.

ONG, Aihwa, 1999, Flexible Citizenship: The Cultural Logic of Transnationality. Durham, NC, Duke University Press.

ORTIZ, Fernando, 1983 [1963], Contrapunteo Cubano del Tabaco y el Azúcar. La Habana, Editorial de Ciencias Sociales.

PALERM, Ángel, 2008a [1980], "La formación colonial mexicana y el primer sistema económico mundial”, in A. Palerm, Antropología y Marxismo. México, DF, Centro de Investigaciones y Estudios Superiores en Antropología Social, Universidad Autónoma Metropolitana, Universidad Iberoamericana, 149-196.

PALERM, Ángel, 2008b [1980], “Antropología y marxismo en crisis”, in A. Palerm, Antropología y Marxismo. México, DF, Centro de Investigaciones y Estudios Superiores en Antropología Social, Universidad Autónoma Metropolitana, Universidad Iberoamericana, 49-77.

REGUILLO, Rosana, 2003, "Jóvenes y estudios culturales: notas para un balance reflexivo”, in José Manuel Valenzuela Arce (ed.), Los Estudios Culturales en México. México, DF, Fondo de Cultura Económica, 354-379.

RICHARD, Nelly (ed.), 2010, En Torno a los Estudios Culturales: Localidades, Trayectorias y Disputas. Santiago, ARCIS/CLACSO.

ROBLES, Anabel, 2015, La Ciudad del Delirio y la Radio que Lo-cura: Etnografía Especular de la Locura en la Ciudad de México y el Papel de los Participantes de Radio Abierta en la Construcción de Una Economía Política de los Afectos. México, DF, Universidad Autónoma Metropolitana, B. A. thesis. 
ROSALDO, Renato, 1994, "Whose cultural studies?", American Anthropologist, 96 (3): 524-529 .

ROUSE, Roger, 1989, Mexican Migration to the United States: Family Relations in the Development of a Transnational Circuit. Stanford, CA, Stanford University, Ph.D. Dissertation.

SAÏD, Edward, 1990 [1978], Orientalismo. Madrid, Libertarias.

SAPIR, Edward, 1924, "Culture, genuine and spurious", American Journal of Sociology, 29 (4): 410-429.

SASSEN, Saskia, 1991, The Global City: New York, London, Tokyo. Princeton, NJ, Princeton University Press.

SEGAL, Daniel, and Sylvia YANAGISAKO (eds.), 2005, Unwrapping the Sacred Bundle: Reflections on the Disciplining of Anthropology. Durham, NC, Duke University Press.

SPIVAK, Gayatri, 1989, “Who claims alterity?”, in Barbara Kruger and Mariana Phil (eds.), Remaking History. Seattle, Bay Press, 269-293.

SZURMUK, Mónica, and Robert McKee IRWIN (eds.), 2009, Diccionario de Estudios Culturales Latinoamericanos. México, DF, Instituto Mora and Siglo XXI.

THOMPSON, E. P., 1978, "Eighteenth-century English society: class struggle without class?", Social History, 3 (2): 133-165.

TYRREL, Ian, 2001, "New comparisons, international worlds: transnational and comparative perspectives", Australian Feminist Studies, 16 (36): 355-361.

VALENZUELA ARCE, José Manuel (ed.), 2015, El Sistema es Antinosotros: Culturas, Movimientos y Resistencias Juveniles. México, DF, Universidad Autónoma Metropolitana.

VELASCO ORTIZ, Laura, 2002, El Regreso de la Comunidad: Migración Indigena y Agentes Étnicos: Los Mixtecos en la Frontera México Estados Unidos. Tijuana, BC, El Colegio de México.

VELASCO ORTIZ, Laura (ed.), 2015, Migración, Fronteras e Identidades Étnicas Transnacionales. Tijuana, BC, El Colegio de la Frontera Norte.

VERTOVEC, Steven, 2006, “Transnacionalismo migrante y modos de transformación” in A. Portes, L. Guarnizo and P. DeWind (eds.), Repensando las Migraciones: Nuevas Perspectivas Teóricas y Empíricas. México, DF, Instituto Nacional de Migración/Universidad Autónoma de Zacatecas/Miguel Ángel Porrúa, 157-190.

WILLIAMS, Raymond, 1977, Marxism and Literature. Oxford, Oxford Univesrity Press.

WIMMER, Andreas, and Nina GLICK SCHILLER, 2002, "Methodological nationalism and beyond: nation-state building, migration and the social sciences", Global Networks, 2 (4): 301-334.

WOLF, Eric, 1987 [1982], Europa y la Gente Sin Historia. México, DF, Fondo de Cultura Económica.

Receção da versão original / Original version

Receção da versão revista / Revised version

Aceitação / Accepted
$2016 / 11 / 26$

$2018 / 02 / 02$

$2018 / 02 / 28$ 